\title{
CHOLINESTERASE DISTRIBUTION DURING SPERMATID DIFFERENTIATION AND SPERMATOZOAL MATURATION IN THE WHITE MOUSE
}

\author{
JYOTSNA GHAKRABORTY AND L. NELSON \\ Department of Physiology, Medical College of Ohio, \\ Toledo, Ohio 43614, U.S.A.
}

(Received 10th Fuly 1973)

\begin{abstract}
Summary. The reaction sites of acetyl and non-specific cholinesterases were located in the electron microscope in spermatogenic tissue and mature spermatozoa of the white mouse. A variety of substrates and inhibitors were used to distinguish between the two groups of enzymes. The shifting distribution of the cholinesterases during sperm cell development and maturation indicates that the origin and fate of the acetylcholine-cholinesterase system may be correlated with the initiation and control of sperm motility. During spermiogenesis, the cholinesterases first appeared in the plasma membrane of the early spermatid. With the gradual development of the spermatids, the reactivity increased; a large amount of reaction product appeared in the neck region, in the fibrillar components and in the cytoplasm of the maturing spermatozoa. As the spermatozoa were liberated into the lumen, much of the enzyme was discarded through the residual bodies. The smooth-surfaced endoplasmic reticulum of Sertoli cells, sub-surface cisternae and the filament bundle of the 'mantle' always reacted strongly. In mature spermatozoa, the main reaction sites shifted to the fibrillar components. Some reactivity might also be noticed at the plasma membrane and mitochondrial surfaces. During maturation in the epididymis, the spermatozoa discarded an additional amount of enzyme along with the cytoplasmic droplet.
\end{abstract}

\section{INTRODUCTION}

The organization of the contractile proteins within the fibrillar elements may confer automaticity of the sperm tail's repetitive contraction-relaxation cycles (Brokaw, 1972), but the variable swimming speeds exhibited by spermatozoa appear to be determined by intrinsic control processes (Nelson, 1972a, b). In response to extraneous environmental conditions, acetylcholine, which functions as mediator of impulse transmission in a variety of excitable systems, may serve a similar function in regulating sperm motility. Acetylcholinesterase may provide for the periodic restoration of flagellar membranes from the 'depolarized' state (A. V. McGrady \& L. Nelson, unpublished observations). 
A number of investigators have shown that at the fine structure level, as well as physiologically, acetylcholinesterase is associated with conductile tissues, nerve fibres and ganglia and at their connections (neuromuscular junctions and synapses) in a wide range of organisms. Effectors such as rat cardiac muscle (Karnovsky, 1964), electroplaques of the electric eel (Bloom \& Barrnett, 1966) and the submandibular gland (Bogart, 1970) contain large amounts of the enzyme. The modern technique of using thiocholine esters, employed as specific substrates, provides a sharp localization of the enzyme reaction product.

Although spermatozoan cholinesterase has been detected biochemically in several species, including boar (Sekine, 1951), ram (Mann, 1954), trout and perch (Tibbs, 1960), mussel (Applegate \& Nelson, 1962) and bull (Nelson, 1964, 1966), it has not been completely characterized nor has there been a systematic examination of the distribution of cholinesterases during sperm cell development. The present study of the dynamics of the distribution of cholinesterase in developing spermatids and maturing spermatozoa of the white mouse was therefore directed to help assess this enzyme's rôle in sperm motility.

\section{MATERIALS AND METHODS}

To prepare the spermatids and immature spermatozoa from the testis and the mature spermatozoa from the cauda epididymidis and ductus deferens, white mice were infused through the dorsal aorta with $3 \%$ formaldehyde and $1 \%$ glutaraldehyde in $0.1 \mathrm{M}-\mathrm{NaH}$ maleate buffer, made isotonic with sucrose (Karnovsky, 1965). After perfusion, the entire reproductive tract was excised and placed in fresh fixative for $20 \mathrm{~min}$ at room temperature. The reproductive tract was then washed with $0.1 \mathrm{~m}-\mathrm{NaH}$ maleate buffer (sodium hydrogen maleate buffer was prepared according to Karnovsky's procedure: $26.9 \mathrm{ml}$ of $0.2 \mathrm{~m}-\mathrm{NaOH}$ plus $50 \mathrm{ml}$ of $0.2 \mathrm{~m}-\mathrm{NaH}$ maleate was made up to $200 \mathrm{ml}$ with water). The $0.2 \mathrm{M}-\mathrm{NaH}$ maleate was prepared by dissolving $23.2 \mathrm{~g}$ maleic acid (or $19.6 \mathrm{~g}$ maleic anhydride) and $8 \mathrm{~g} \mathrm{NaOH}$ in water and making the volume to $1000 \mathrm{ml}$ ) and divided into its components. Each of these parts was sliced further with a Sorvall, Smith and Farquhar tissue chopper. These sections were then transferred to the buffer solution before being placed in the different incubation media, which contained the buffer and either substrate or inhibitor, or in the medium lacking both for preparation of the control specimens.

\section{Histochemical tests}

The tissue specimens were grouped into three sets for each experiment. The experiment was subsequently repeated twenty times with a total of forty animals of about the same age.

The first set of tissues was treated with different substrates for various times, temperatures and concentrations. The substrates made up in a medium similar to Karnovsky's (Karnovsky, 1964; Karnovsky \& Roots, 1964) included the following: (a) acetylthiocholine iodide (AcThChI); (b) butyrylthiocholine iodide (BuThChI); (c) acetyl- $\beta$-methylthiocholine iodide (Ac $\beta$ MeThChI). The substrate concentrations were varied from $1 \mathrm{~mm}$ to $15 \mathrm{~mm}$, and the specimens were allowed to incubate from $10 \mathrm{~min}$ to $2 \mathrm{hr}$. The best results were obtained 
using an $8 \mathrm{~mm}$-substrate concentration at room temperature for $30 \mathrm{~min}$. These conditions provided for optimum activity, highest contrast, sharpest definition, and minimized diffusion.

The second set of tissues was preincubated with one of the following inhibitors: 1,5-bis (4'-para-allyldimethyl ammonium phenyl)pentanone-3 dibromide (BW284C51, Burroughs Wellcome \& Company), specific for true acetylcholinesterase; eserine sulphate, a general cholinesterase inhibitor (Nutritional Biochemical Company); tetraisopropylpyrophosphoramide (Iso-OMPA, Sigma Chemical Company); and RO20683, which specifically block pseudocholinesterase (Hoffman-LaRoche). The pretreatments were also conducted in varying concentrations of inhibitors ( $1 \mathrm{~mm}$ to $8 \mathrm{~mm}$ ). After preincubation, the tissues were subsequently incubated in the media containing both inhibitor and substrate.

The third set of the tissue series served as the control. The composition of the control medium was the same as above, lacking only the substrate and inhibitor. The control specimens were incubated under the same conditions of time and temperature.

\section{Electron microscopy}

After histochemical treatment, each set of tissues was washed with $\mathrm{NaH}$ maleate buffer and then post-fixed with $1 \% \mathrm{OsO}_{4}$ in Zetterqvist (1956) buffer for $1 \mathrm{hr}$ at $\mathrm{pH}$ 7.2. After dehydration, the tissues were embedded in Epon 812 (Luft, 1961). Thick $(1 \mu \mathrm{m})$ sections were examined to locate similar areas from each block, and then thin $(\sim 900 \AA)$ sections cut with the LKB ultratome were picked up on 100-mesh Formvar-coated copper grids. Further staining was not done, though it was found that lead and uranyl stain did not interfere with the cytochemical reactions. The sections were then examined in the Philips EM 300 electron microscope.

\section{RESULTS}

\section{Enzymatic activity in the developing spermatids}

Four different phases, the Golgi phase, the cap phase, the acrosome phase and the maturation phase, were selected to represent progressive changes in cholinesterase activity in the developing spermatids (according to the staging of Leblond \& Clermont, 1952). Further subdivision into the total of nineteen steps is not considered here for the sake of brevity.

In an early stage of spermatid formation, e.g. the Golgi phase, very little enzyme reaction product was found inside the spermatids. The reaction occurred mainly within the Sertoli cells. Later, during the cap phase (PI. 1, Fig. 1), some reaction product might be seen on the plasma membrane of the spermatids but very little within the cytoplasm. As spermatid development proceeded into the acrosome phase (Pl. 1, Fig. 2), the enzyme activity progressively increased, becoming more prominent later in this phase. Thus the main sites of the enzyme have been found initially to be the spermatid-Sertoli cell junction, on the electron-dense bundles of filaments and sub-surface cisternae of the 'mantle' (Yasuzumi, Tanaka \& Tezuka, 1960; Nicander, 1967; 
Bennett, Gall, Southard \& Sidman, 1971) and little in the spermatid cytoplasm. In the maturation phase, high enzymatic activity appeared at the neck region (Pl. 2, Fig. 3), the filament bundles and sub-surface cisterna of the mantle (Pl. 3, Fig. 4). At the caudal end of the nucleus, the nuclear membrane extended back in to the neck region (Pl. 4, Fig. 5) to form a long membranous fold (Fawcett, 1970). High enzymatic activity was found inside this area (Pl. 4, Fig. 5). Reaction deposits were also found in the fibrillar components and in the cytoplasm (Pl. 2, Fig. 3). During spermateliosis, when spermatozoa are liberated into the lumen of the seminiferous tubule as 'free spermatozoa' (Pl. 4, Fig. 6), most of the deposit appeared to be associated with the coarse fibres and the axonemal doublets of the tail, as well as with the cytoplasm separated from the cell in the form of the 'residual body' (Pl. 5, Fig. 7). The reaction product was also seen in the small amount of cytoplasm surrounding the free spermatozoa (Pl. 4, Fig. 6).

\section{Mature spermatozoa}

In the spermatozoa occupying the cauda epididymidis and ductus deferens (Pl. 6, Fig. 8), the enzyme distribution remained similar to that in the free spermatozoa contained in the lumen of the seminiferous tubule (Pl. 4, Fig. 6). The activity was mainly associated with the axonemal doublets and the coarse fibres, but very little of the reaction product could be seen at the neck region. Occasionally a few dense particles were noticed on the mitochondria as well as attached to the plasma membrane surfaces. Although it was difficult to determine the extent to which mitochondrial regions and plasma membrane were involved with this type of enzymatic activity, it was apparent under the conditions of the present study that a rather limited quantity of the enzyme was present in those areas. Whereas the seminiferous tubule lumen seemed to be completely devoid of reaction deposit (Pl. 4, Fig. 6), quite large amounts of

\section{EXPLANATION OF PLATES 1 TO 3}

\section{PLATE 1}

FIG. 1. White mouse spermatid in the cap phase of development. Treated with $15 \mathrm{~mm}$ AcThChI for $30 \mathrm{~min}$ (all specimens incubated at room temperature). The dark deposits on the plasma membrane (PM, arrows) and in the cytoplasm (double arrow) of the spermatid (SP) and the cisterna of smooth endoplasmic reticulum (double arrows) of the Sertoli cell (S) are the reaction product. $\times 41,000$.

Fia. 2. Spermatid in the acrosome phase. Treated with $8 \mathrm{~mm}$-AcThChI for $30 \mathrm{~min}$. The developing head $(\mathrm{H})$ is surrounded by Sertoli cell $(\mathrm{S})$ cytoplasm. The reaction product is seen in the sub-surface cisterna $(C)$ and the filament bundle $(F)$ of the mantle $(M)$. $\times 29,412$.

\section{PLATE 2}

Frg. 3. Two white mouse spermatids in the late maturing phase with dense head $(\mathbf{H})$. Treated with $12 \mathrm{~mm}$-AcThChI for $30 \mathrm{~min}$. Sertoli cell (S) smooth endoplasmic reticulum cisterna (arrow), neck region (NR), fibrillar components of the mid-piece (FC) and the maturing sperm cytoplasm (double arrows) containing reaction product. $\times 27,360$.

\section{PLATE 3}

Fig. 4. Head of a white mouse maturing spermatid surrounded by Sertoli cell cytoplasm. Treated with $8 \mathrm{~mm}-\mathrm{Ac} \beta \mathrm{MeThChI}$ for $30 \mathrm{~min}$. The filament bundle $(\mathrm{F})$, sub-surface cisterna (C) of mantle (M) and cisterna of smooth endoplasmic reticulum of Sertoli cell (S) contain dark reaction deposits (arrows). $\times 26,700$. 
PLATE 1

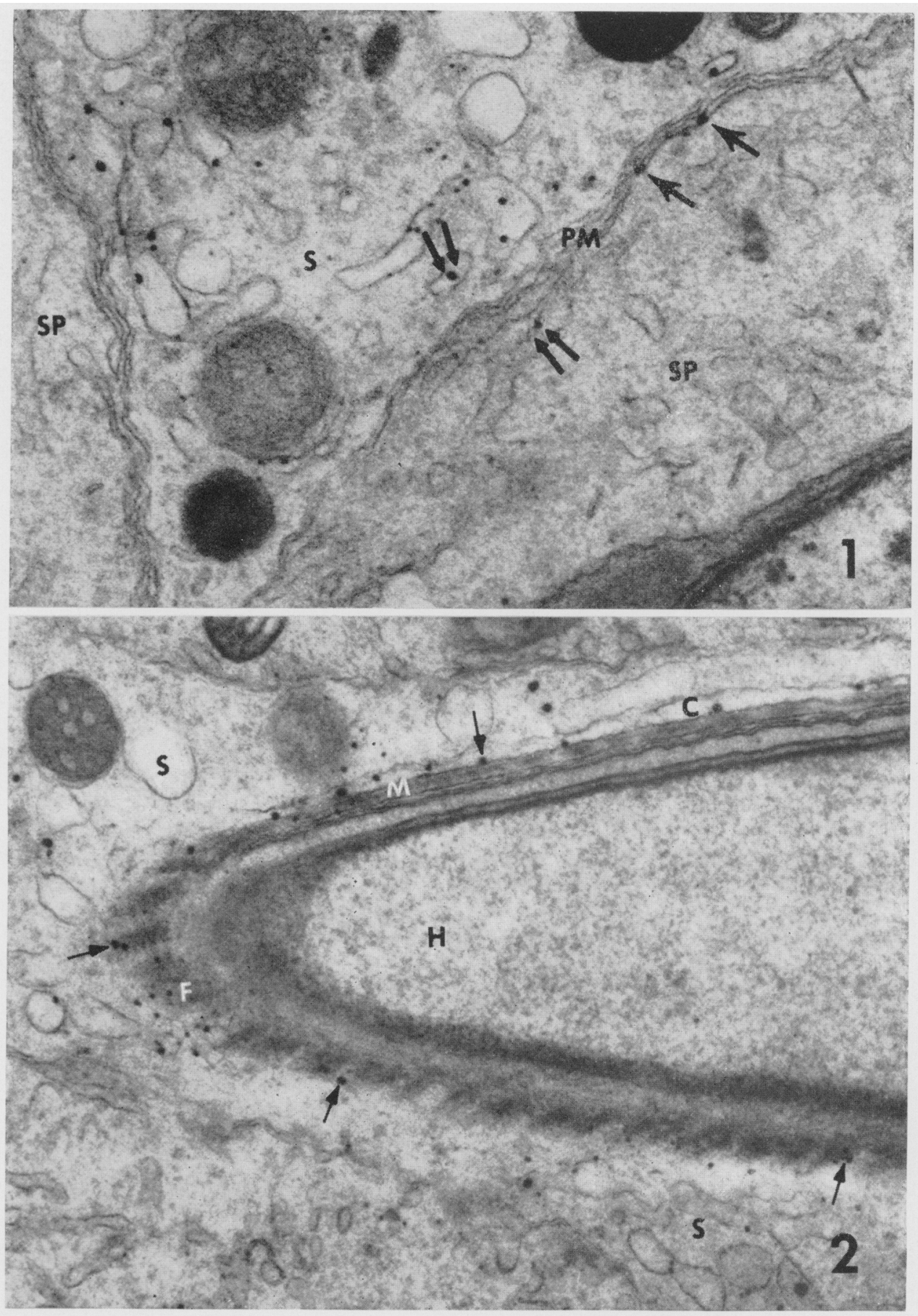

(Facing p. 362) 


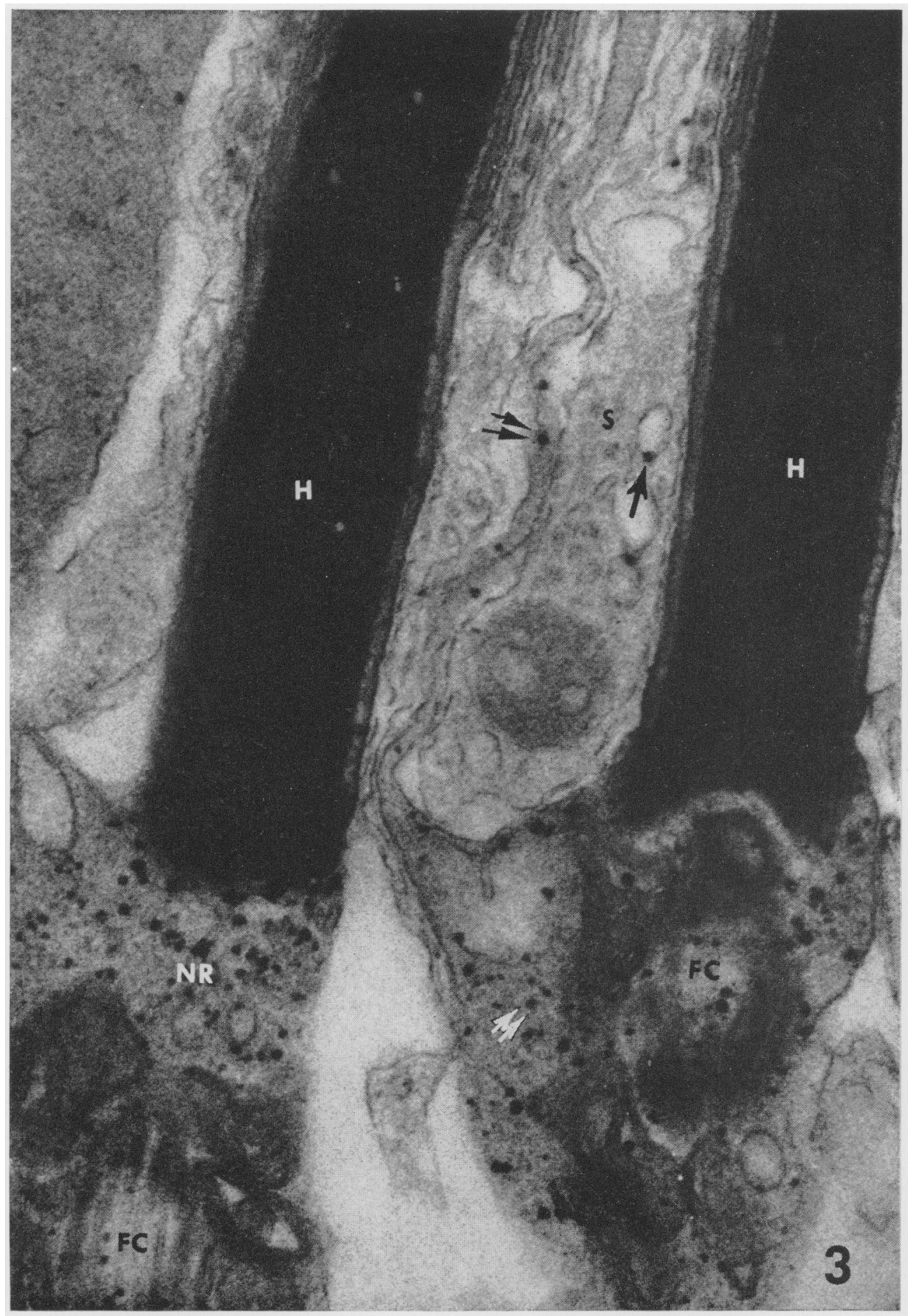




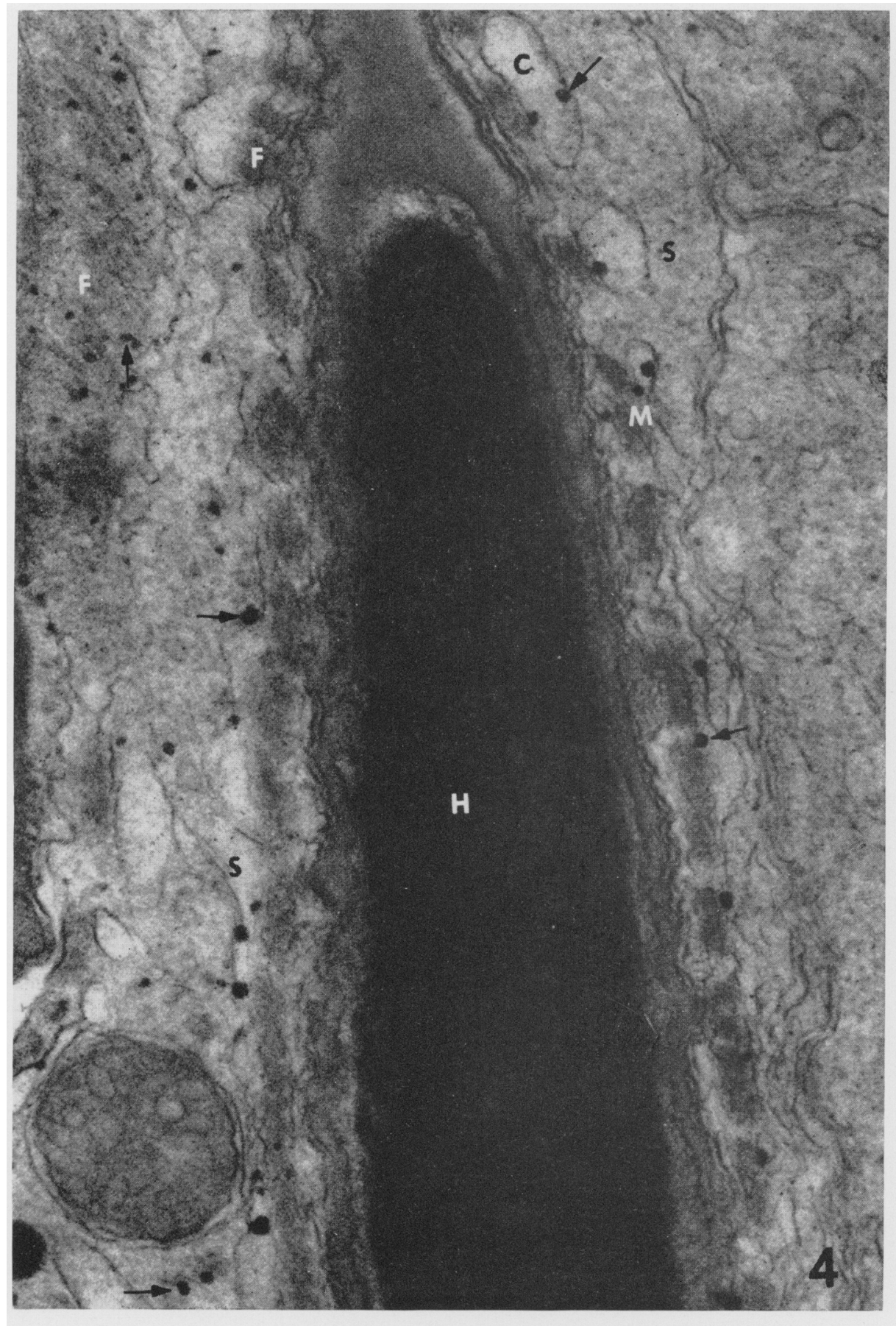


electron-dense particles were always found in the fluid within the ductus deferens (PI. 6, Fig. 8). A complete absence of the reaction product from all the control groups confirmed the enzymatic basis of the cytochemical reaction ( $\mathrm{Pl}$. 6, Fig. 9).

\section{Sertoli cells}

Normally developing spermatids occur in intimate association with the Sertoli cells. In Sertoli-cell cytoplasm, the agranular endoplasmic reticulum was more prominent than the rough-surfaced endoplasmic reticulum. The agranular endoplasmic reticulum existed in the form of a web of tubules and cisternae, most of which contained dense reaction deposits (Pl. 7, Fig. 10). Sertoli cell

Table 1. Effect of three different substrates on cholinesterase activity on cells from the male reproductive tract of white mice

\begin{tabular}{|c|c|c|c|c|}
\hline \multirow{2}{*}{ Cell } & \multirow{2}{*}{ Organelle } & \multicolumn{3}{|c|}{ Substrate } \\
\hline & & AcThChI & $B u T h C h I$ & $A c \beta M e T h C h I$ \\
\hline \multirow[t]{2}{*}{ Spermatids } & $\begin{array}{l}\text { Neck region } \\
\text { Fibrillar component } \\
\text { Cytoplasm } \\
\text { Residual body }\end{array}$ & +++ & ++ & ++ \\
\hline & $\begin{array}{l}\text { Nucleus } \\
\text { Mitochondria } \\
\text { Golgi, acrosome }\end{array}$ & - & - & - \\
\hline Sertoli-spermatid junction & $\begin{array}{l}\text { Filament bundle } \\
\text { Sub-surface cisterna } \\
\text { Intercellular space }\end{array}$ & +++ & ++ & ++ \\
\hline \multirow[t]{2}{*}{ Sertoli cells } & Smooth surface E.R. cisterna & +++ & ++ & ++ \\
\hline & $\begin{array}{l}\text { Nuclei } \\
\text { Golgi } \\
\text { Mitochondria }\end{array}$ & - & - & - \\
\hline \multirow[t]{2}{*}{ Spermatozoa } & $\begin{array}{l}\text { Fibrillar component } \\
\text { Fibrous sheath } \\
\text { Plasma membrane }\end{array}$ & +++ & ++ & ++ \\
\hline & $\begin{array}{l}\text { Head } \\
\text { Acrosome }\end{array}$ & - & - & - \\
\hline
\end{tabular}

E.R. = endoplasmic reticulum. For substrate abbreviations, see text. +++ , High reactivity; ++ , moderate reactivity; - , negative reactivity.

processes projecting into the spermatid cytoplasm appeared to contain tubules and cisternae with the enzyme reaction occurring inside them. In mouse testis, the junctions between the Sertoli cell and late spermatids have unusual characteristics. A layer of fine filaments associated with a sub-surface cisterna of smooth endoplasmic reticulum occurs only on the Sertoli cell side. This specialized structure is called the 'mantle' (Brökelmann, 1963; Flickinger \& Fawcett, 1967; Bennett et al., 1971). The sub-surface cisterna of the mantle also contained considerable amounts of the enzyme (Pl. 1, Fig. 2 and Pl. 3, Fig. 4).

Specificity of the substrates

The three different substrates, AcThChI, Ac $\beta$ MeThChI and BuThChI, 
yielded the same product in nearly the same places (Table 1). A large number of the dense particles also appeared in the lumen of the ductus deferens and the cauda epididymidis when incubated with AcThChI. The lowest limiting concentration of substrate $(1 \mathrm{~mm})$ gave very little reaction, whereas the higher concentrations ( $8 \mathrm{~mm}$ to $15 \mathrm{~mm}$ ) provided sharp localization. The product formed optimally in $8 \mathrm{~mm}$ substrate, a concentration above which no increase

Table 2. Effect of inhibitors on cholinesterase activity

\begin{tabular}{l|c|c|c|c}
\hline \multirow{2}{*}{ Substrate } & \multicolumn{4}{|c}{ Inhibitor } \\
\cline { 2 - 5 } & Eserine & BW284C51 & Iso-OMPA & RO20683 \\
\hline AcThChI & +++ & ++ & + & + \\
BuThChI & +++ & + & ++ & ++ \\
Ac $\beta$ MeThChI & +++ & ++ & + & + \\
\hline
\end{tabular}

+++ , Complete inhibition; ++ , moderate inhibition; + , very little inhibition.

in activity was noticed. Acetyl- $\beta$-methylthiocholine iodide, which has been reported to be a most specific substrate for acetylcholinesterase (Kokko, Mautner \& Barrnett, 1969), yielded the reaction product at very much the same sites, but the amount of reaction product was somewhat restricted.

\section{Effect of inhibitors}

Eserine sulphate, which, though a non-specific inhibitor of cholinesterases in general, acts as a competitive inhibitor of acetylcholinesterase, blocked the

\section{EXPLANATION OF PLATES 4 TO 7}

\section{PLATE 4}

Fig. 5. Portion of maturing sperm cell treated with $8 \mathrm{~mm}$-AcThChI for $15 \mathrm{~min}$. Reaction deposit (arrow) is seen within the space surrounded by the folded back nuclear membrane $(\mathrm{NM})$ in the neck region and within the cytoplasm (CP). $\times 37,600$.

Frc. 6. Portion of free white mouse sperm cells in the lumen of the seminiferous tubule. Treated with $12 \mathrm{~mm}$-AcThChI for $30 \mathrm{~min}$. The fibrillar component (single arrows), surrounding cytoplasm (double arrows) and plasma membrane (large arrow) contain reaction deposit. No free particles of reaction deposit are seen. $\times 20,500$.

\section{PLATE 5}

FIg. 7. Residual body. Treated with $12 \mathrm{~mm}$-AcThChI for $30 \mathrm{~min}$. Arrows indicate the reaction deposit within the residual body $(R), \times 47,900$.

\section{PLATE 6}

FIG. 8. Tails of mature white mouse sperm cells in the lumen of the ductus deferens. Treated with $8 \mathrm{~mm}-\mathrm{AcT}$ ThChl for $30 \mathrm{~min}$. The reaction deposits (single arrows) are found free in the lumen in addition to those (double arrows) in the fibrillar components and on the plasma membrane of the spermatozoa. $\times 25,000$.

FIG. 9. Mature spermatozoa in the lumen of the ductus deferens. Control experiment: treated with substrate-free medium for $30 \mathrm{~min}$. Note the complete absence of the reaction product. $\times 28,000$.

\section{PLATE 7}

FIG. 10. Portion of a white mouse Sertoli cell (S) surrounding spermatids (SP). The smooth endoplasmic reticulum cisternae of the Sertoli cell contain dark reaction deposit (arrows). $\times 59,500$. 
PLATE:

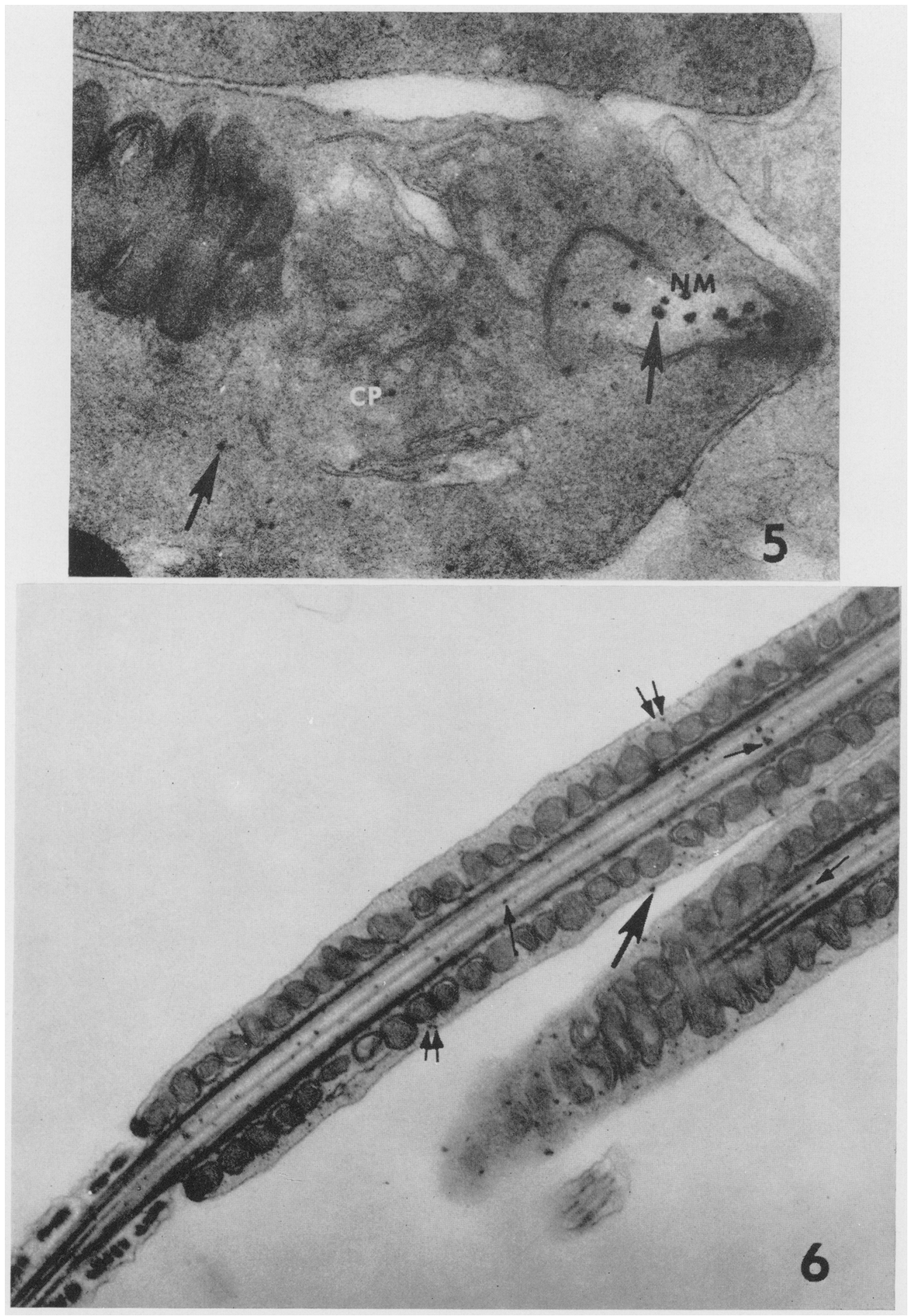

(Facing p. 364) 
PLATI: 5

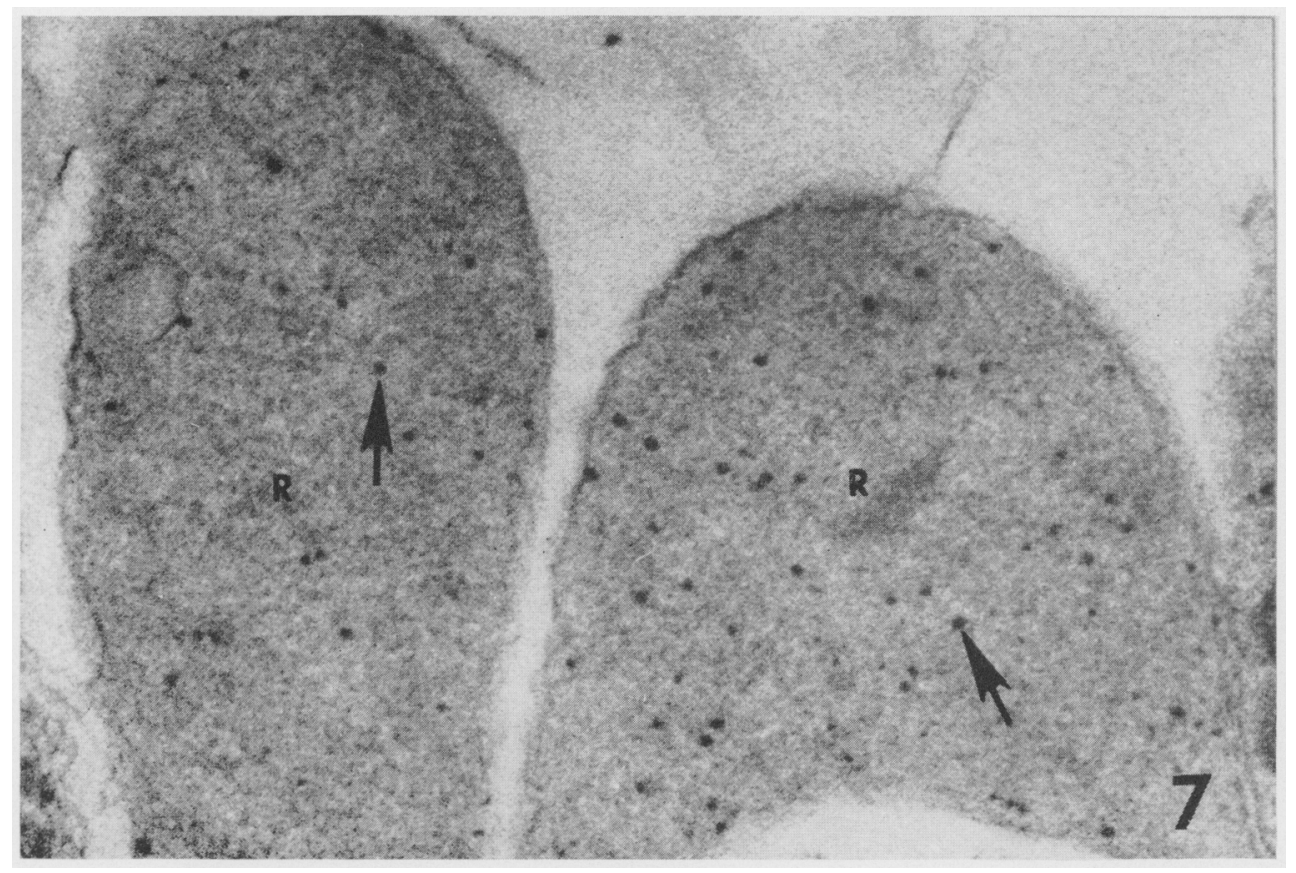


PLATE 6

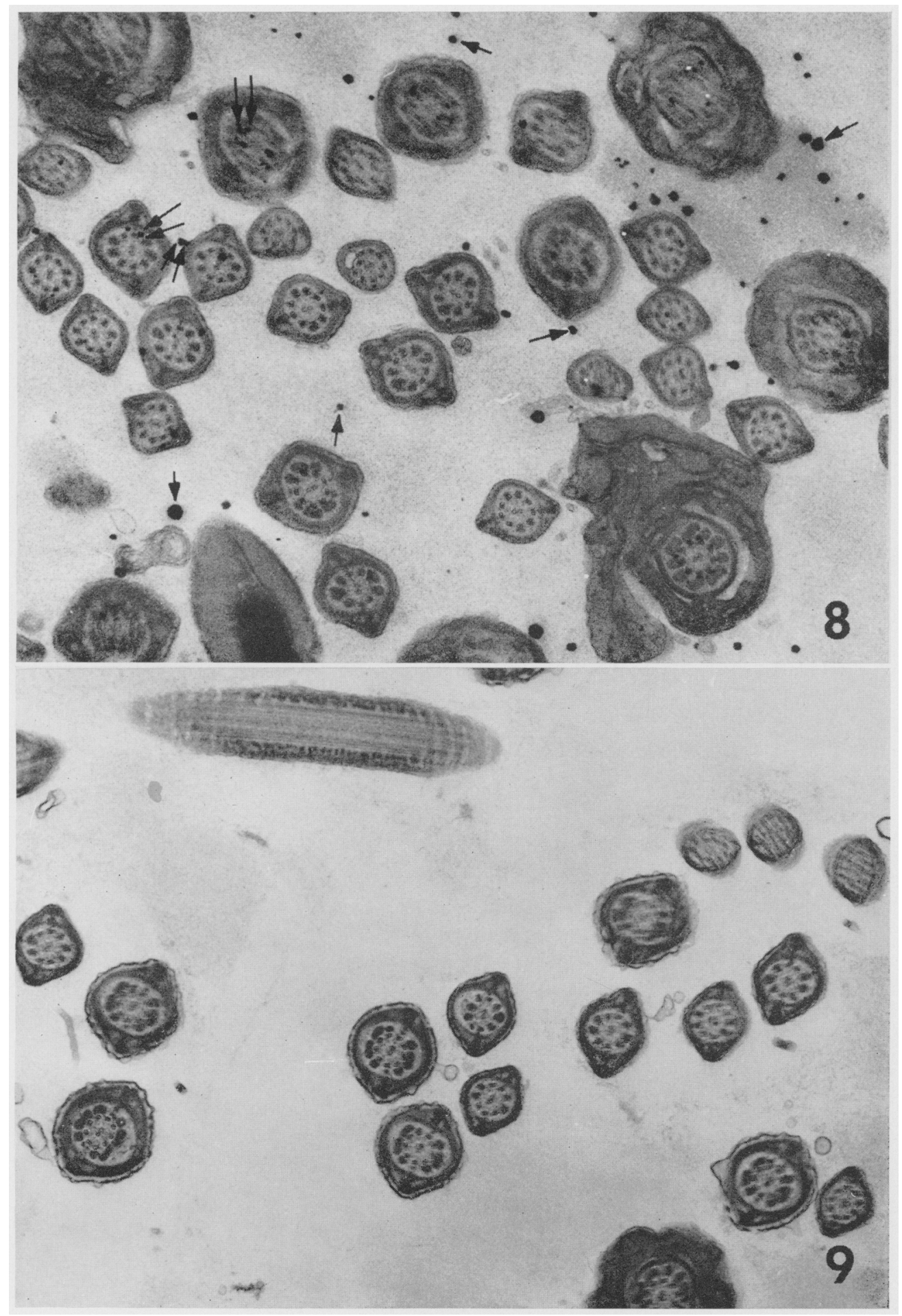


PLATE 7

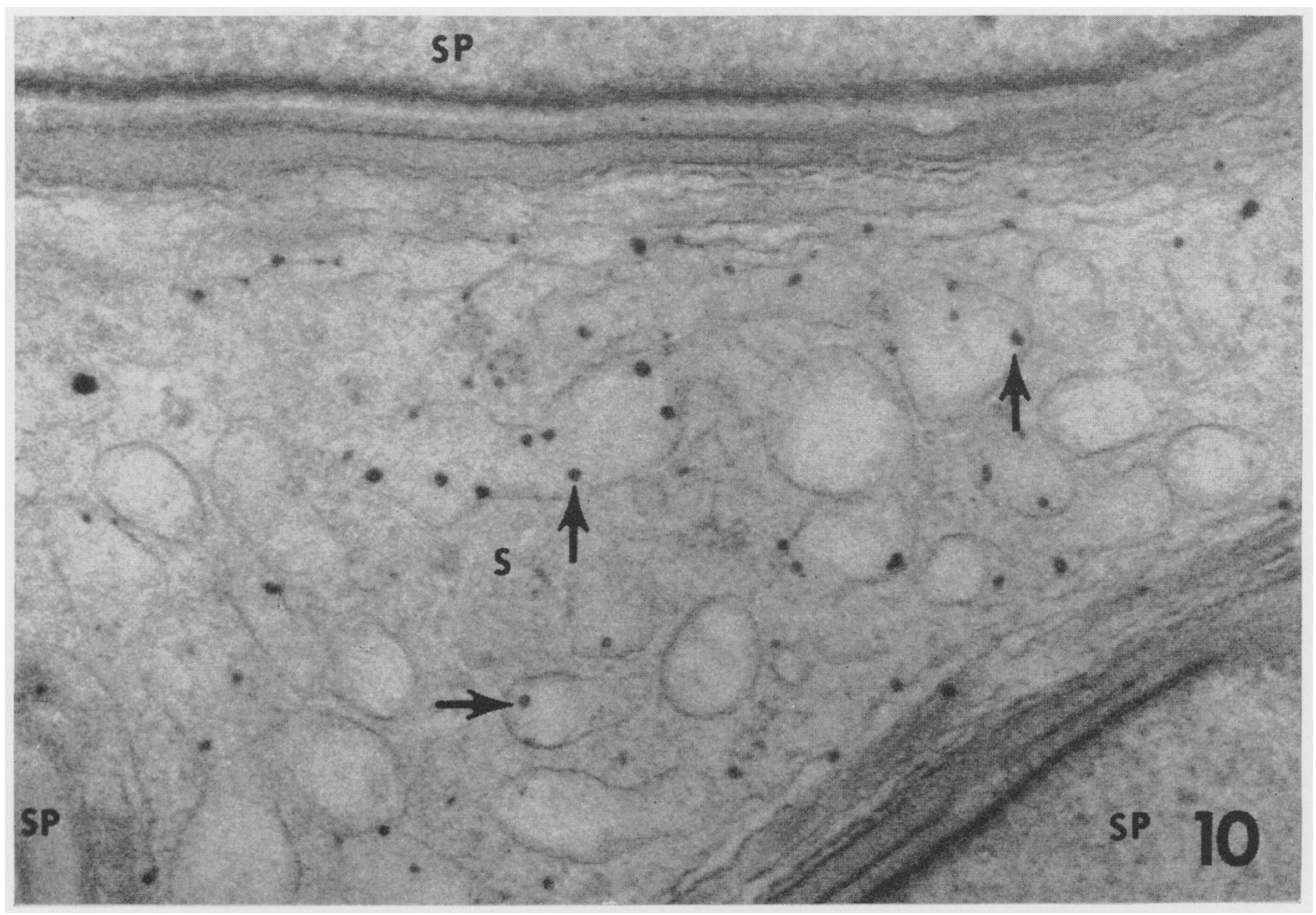

(Facing p. 365) 
reaction completely when the tissue was pretreated in the eserine-containing medium and then subsequently incubated in the medium containing both the eserine and the substrate. An inhibitor of specific acetylcholinesterase, BW284C51, and both RO20683 and Iso-OMPA, which specifically inhibit pseudocholinesterase, were also tested. The reaction was partly inhibited by BW284C51. Similarly, when the tissue was treated with RO20683 and Iso-OMPA, only partial inhibition occurred. These observations have been summarized in Table 2.

\section{Effects of time and temperature of incubation}

Long periods of incubation were not essential. In $10 \mathrm{~min}$ of incubation, the reaction product began to appear, while $30 \mathrm{~min}$ of incubation gave the best result, and very little of the product appeared to diffuse since the incubating medium remained clear even after $150 \mathrm{~min}$.

The incubation temperature considerably affected the cholinesterase activity. At $4^{\circ} \mathrm{C}$, very little reaction product was seen even in very high concentrations (15 mM) of the substrate and after $60 \mathrm{~min}$ of incubation. Incubation at room temperature, at lower substrate concentration $(8 \mathrm{~mm})$ and for a shorter period $(30 \mathrm{~min})$ gave the best results. Higher temperatures were not tried.

\section{DISGUSSION}

\section{Histochemical reactions}

The tissue, incubated in the Karnovsky medium with specific thiocholine esters, hydrolyses the substrate initiating a stepwise series of reactions. Thiocholine released by hydrolysis of the substrate reduces potassium ferricyanide to ferrocyanide; the ferrocyanide combines with copper in the medium forming insoluble copper ferrocyanide. False positive reactions can readily occur leading to the formation of non-specific deposits in the later stages of the stepwise process resulting in contamination, unless extreme care is taken throughout the entire procedure. The numerous replications confirmed the localization of the enzyme at the ultrastructural level.

Incubation in either AcThChI or BuThChI yields a considerable amount of reaction product. Eserine prevents the reactions altogether. The inhibitors, Iso-OMPA, BW284C51 and RO20683, have a partial effect, which suggests that both pseudo- (non-specific) cholinesterase and specific acetylcholinesterase coexist in these cells. In the presence of $\mathrm{Ac} \beta \mathrm{MeThChI}$, a substrate specifically hydrolysed by acetylcholinesterase, very sharp deposits without diffusion appear, again verifying the presence of true acetylcholinesterase. The complete absence of autocatalytic deposits or contamination in the control preparations even after prolonged incubation confirms both the identity and the specificity of the reaction in the presence of the appropriate substrate. Table 2 summarizes the data with the various substrates and the inhibitors.

\section{Rôle of the enzyme in sperm motility}

Characteristically, acetylcholinesterase occurs at the sites of structures responsible for impulse transmission and in association with tissues exhibiting rhyth- 
mic activity. By biochemical assay, Nelson (1966) found that acetylcholinesterase was confined to the flagella (both motile and non-motile) of naturally decapitated bull spermatozoa. It was difficult to determine, however, whether this enzyme was primarily responsible for the initiation of flagellation, propagation of the flagellar wave or co-ordination of contraction of longitudinal flagellar fibres. Even though large amounts of the enzyme appeared to be associated with the 'residual' cytoplasm, we observed in the present study that in mature spermatozoa the fibrillar components of the tail retained most of what was left. This observation supplies morphological evidence in support of the suggestion that the propagation of the flagellar wave and the co-ordination of contraction of the flagellar system may be regulated by the acetylcholinecholinesterase system. Several investigators have suggested that Sertoli cells resorb the residual bodies cast off by the spermatids (Dietert, 1966; Nicander, 1967). Others believe that the Sertoli cell may enter into material transfer with the maturing germ cells (Courot, Hochereau-de Reviers \& Ortavant, 1970). The enzyme accumulation at the Sertoli cell interfaces with the developing spermatids could represent this phenomenon.

The appearance of the enzyme in the plasma membrane of the early spermatid may contribute to the generation of impulses responsible for the slow undulatory movements of the cell surface described by Clermont (1964); with further development of the spermatid, the increased amount of the enzyme in the cytoplasm may underlie the rhythmic beat and the partial lateral twist of the caudal 'paddle-shaped pole' (Clermont, 1964). As the maturing spermatids begin to move towards the lumen, a large amount of the cholinesterase accumulates in the neck region. During spermateliosis, the extra amount of the enzyme could assist in mediating the generation of propulsive forces that result in liberating the maturing spermatozoon from the Sertoli cells. Upon extrusion of the spermatozoa into the lumen, the enzyme concentrated at the neck region presumably accompanies the other superfluous constituents voided through the cytoplasmic droplets. In the mature spermatozoon, the flagellar system and the fibrous sheath apparently require a relatively small amount of the cholinesterase in the membrane-associated sites to assure regulation of flagellar activity through periodic reversal of the cycles of depolarization. In experiments described elsewhere (Nelson, 1972a, b), the swimming speed of sea-urchin spermatozoa responds in dose-dependent fashion to acetylcholine, to inhibitors of acetylcholine synthesis and hydrolysis, and also to blockers of impulse transmission. It now appears that bull spermatozoa may also prove to be as sensitive to these pharmacological agents (experiments in progress); the observed distribution of the acetylcholinesterase at the subcellular level could readily account for a cholinergic control mechanism.

\section{ACKNOWLEDGMENTS}

The authors thank Mrs Margaret Cousino, Mrs Judith Price, Miss Marianne Ireland and Miss Joan Tolford for their skilful technical assistance and Mrs Josette Tolford for typing the manuscript. This work was partly supported by USPHS Research Grant HD R01-03266-04 and Research Contract NIH 702313 of the NICHD Center for Population Research. 


\section{REFERENCES}

Applegate, A. \& Nelson, L. (1962) Acetylcholinesterase in Mytilus spermatozoa. Biol. Bull mar. biol. Lab., Woods Hole, 123, 475.

Bennett, W. I., Gall, A. M., Southard, J. L. \& Sidman, R. L. (1971) Abnormal spermiogenesis in quaking, a myelin-deficient mutant mouse. Biol. Reprod. 5, 30.

BLOOM, F. E. \& BarRnetT, R. J. (1966) Fine structural localization of acetylcholinesterase in electroplaque of the electric eel. . Cell Biol. 29, 475.

Bogart, B. I. (1970) Fine structural localization of cholinesterase activity in the rat submandibular gland. F. Histochem. Cytochem. 18, 730.

BRoKaw, C. (1972) Flagellar movement: a sliding filament model. Science, N.Y. 178, 455.

BRökelmanN, J. (1963) Fine structure of germ cells and Sertoli cells during the cycle of the seminiferous epithelium in the rat. Z. Zellforsch. mikrosk. Anat. 59, 820.

Glermont, Y. (1964) Motility of the flagellum and cytoplasmic membrane of the rat spermatids. Anat. Rec. 148, 271.

Courot, M., Hochereau-de Reviers, M. T. \& Ortavant, R. (1970) Spermatogenesis. In The Testis, Vol. 1, pp. 339-432. Eds. A. D. Johnson, W. R. Gomes and N. L. VanDemark. Academic Press, New York.

DiEtert, S. E. (1966) Fine structure of the formation and fate of the residual bodies of mouse spermatozoa with evidence for the participation of lysosomes. $\mathcal{F}$. Morph. 120, 317.

Fawcetr, D. W. (1970) A comparative view of sperm ultrastructure. Biol. Reprod., Suppl. 2, 90.

FLICKInger, C. \& FAwCETT, D. W. (1967) The junctional specializations of Sertoli cells in the seminiferous epithelium. Anat. Rec. 158, 207.

Karnovsky, M. J. (1964) The localization of cholinesterase activity in rat cardiac muscle by electron microscopy. 7. Cell Biol. 23, 217.

Karnovsky, M.J. (1965) A formaldehyde-glutaraldehyde fixative of high osmolarity for use in electron microscopy. 7. Cell Biol. 27, 137a.

Karnovsky, M. J. \& Roots, L. (1964) A 'direct coloring' thiocholine method for cholinesterases. $\mathcal{F}$. Histochem. Cytochem. 12, 219.

Kokko, A., Mautner, H. G. \& Barrnett, R. J. (1969) Fine structural localization of acetylcholinesterase using acetyl- $\beta$-methylthiocholine and acetylthiocholine as substrates. 7. Histochem. Cytochem. 17, 625 .

Leblond, C. P. \& Clermont, Y. (1952) Definition of the stages of the cycle of the seminiferous epithelium in the rat. Ann. N.Y. Acad. Sci. 55, 548.

LuFT, J. H. (1961) Improvements in epoxy resin embedding methods. 7. biophys. biochem. Cytol. 9, 409.

ManN, T. (1954) The Biochemistry of Semen, p. 174. Methuen, London.

Nelson, L. (1964) Acetylcholinesterase in bull spermatozoa. F. Reprod. Fert. 7, 65.

Nelson, L. (1966) Enzyme distribution in 'naturally-decapitated' bull spermatozoa: acetylcholinesterase, adenylpyrophosphatase and adenosinetriphosphatase. F. cell. Physiol. 68, 113.

NeLson, L. (1972a) Quantitative evaluation of sperm motility control mechanisms. Biol. Reprod. 6, 319.

Nelson, L. (1972b) Neurochemical control of Arbacia sperm motility. Expl Cell Res. 74, 269.

NiCANDER, L. (1967) An electron microscopical study of cell contacts in the seminiferous tubules of some mammals. Z. Zellforsch. mikrosk. Anat. 83, 375.

SEkine, T. (1951) Cholinesterase in pig spermatozoa. F. Biochem., Tokyo, 38, 171.

TiBBS, J. (1960) Acetylcholinesterase in flagellated systems. Biochim. biophys. Acta, 41, 115.

Yasuzumi, G., TanakA, H. \& TezukA, O. (1960) Spermatogenesis in animals as revealed by electron microscopy. VIII. Relation between the nutritive cells and the developing spermatids in a pond snail, Cipangopaludina malleata Reeve. 7. biophys. biochem. Cytol. 7, 499.

ZETTERQVIST, H. (1956) The ultrastructural organization of the columnar absorbing cells of the mouse jejunum. Ph.D. thesis, Karolinska Institutet, Stockholm. 